\title{
Chicken Mesenchymal Stem Cells and Their Applications: A Mini Review
}

\author{
Andrea Svoradova (D), Vladimir Zmrhal (D, Eva Venusova and Petr Slama*
}

\section{check for} updates

Citation: Svoradova, A.; Zmrhal, V.; Venusova, E.; Slama, P. Chicken Mesenchymal Stem Cells and Their Applications: A Mini Review. Animals 2021, 11, 1883. https://doi.org/ 10.3390/ani11071883

Academic Editors: Eleonora Iacono and Barbara Merlo

Received: 29 May 2021

Accepted: 19 June 2021

Published: 24 June 2021

Publisher's Note: MDPI stays neutral with regard to jurisdictional claims in published maps and institutional affiliations.

Copyright: (c) 2021 by the authors. Licensee MDPI, Basel, Switzerland. This article is an open access article distributed under the terms and conditions of the Creative Commons Attribution (CC BY) license (https:/ / creativecommons.org/licenses/by/ $4.0 /)$.
Department of Animal Morphology, Physiology and Genetics, Faculty of AgriSciences, Mendel University in Brno, 61300 Brno, Czech Republic; andrea.svoradova@mendelu.cz (A.S.); vladimir.zmrhal@mendelu.cz (V.Z.); eva.venusova@mendelu.cz (E.V.)

* Correspondence: petr.slama@mendelu.cz

Simple Summary: Mesenchymal stem cells (MSCs) are multipotent stem cells that are capable of differentiation into bone, muscle, fat, and closely related lineages and express unique and specific cell surface markers. They can be used as an avian culture model to better understand osteogenic, adipogenic, and myogenic pathways. Moreover, MSCs could also be used as a model to study various developmental and physiological processes in avian and other species. To obtain a comprehensive overview of this topic, the keywords "mesenchymal stem cells", "chicken", "disease", "chicken dermatitis", "viral infections in chicken", and "antibiotics in chicken" were searched in WOS and PUBMED databases to obtain relevant information.

Abstract: Mesenchymal stem cells (MSCs) are multipotent progenitor cells that adhere to plastic; express the specific markers CD29, CD44, CD73, CD90, and CD105; and produce cytokines and growth factors supporting and regulating hematopoiesis. MSCs have capacity for differentiating into osteocytes, chondrocytes, adipocytes, and myocytes. They are useful for research toward better understanding the pathogenic potential of the infectious bursal disease virus, mineralization during osteogenesis, and interactions between MSCs as a feeder layer to other cells. MSCs are also important for immunomodulatory cell therapy, can provide a suitable strategy model for coculture with pathogens causing dermatitis disorders in chickens, can be cultured in vitro with probiotics and prebiotics with a view to eliminate the feeding of antibiotic growth promoters, and offer cell-based meat production. Moreover, bone marrow-derived MSCs (BM-MSCs) in coculture with hematopoietic progenitor/stem cells (HPCs/HSCs) can support expansion and regulation of the hematopoiesis process using the 3D-culture system in future research in chickens. MSCs' several advantages, including ready availability, strong proliferation, and immune modulatory properties make them a suitable model in the field of stem cell research. This review summarizes current knowledge about the general characterization of MSCs and their application in chicken as a model organism.

Keywords: chicken; mesenchymal stem cells; culture; disease; probiotics; applications

\section{Introduction}

As poultry meat production has increased dramatically in recent years, attention is now turning more to ensuring the high quality of that output [1]. Because genetic modification and selection for growth can cause skeletal disorders or muscle degeneration, and thus have negative impacts for the poultry industry [2], innovative methods are important for maintaining production. Mesenchymal stem cells (MSCs) seem to provide a suitable tool for examining skeletal development in poultry. MSCs are multipotent cells able to differentiate into osteocytes, chondrocytes, adipocytes, and myocytes [3]. They have been isolated from many species, including chickens, sheep, cats, dogs, rats, mice, and humans [4-11].

MSCs have the capacity to adhere to plastic surfaces under in vitro conditions and to express several surface antigens [12]. They also have the ability to produce cytokines and 
growth factors, commonly referred to as the MSC secretome, that support and regulate hematopoiesis [13].

MSCs can be used as a model for cell culture to better understand differentiation pathways, as well as to identify supplements that can affect these interactions, and in the areas of viral, skeletal, and immunological research. MSCs have furthermore become a subject of research due to their easy isolation, in vitro proliferation, multi-lineage differentiation, support to hematopoiesis, cytokine and growth factor production, and usefulness for immunomodulatory purposes [14]. Moreover, MSCs are able to migrate through the peripheral circulation to damaged areas, where they proliferate and differentiate, thus facilitating the healing process through the activation of several mechanisms [15]. MSCs are able to reduce cell injury by the synergistic action of small molecules, extracellular vesicles (EVs), secreted by MSCs to maintain tissue homeostasis. Studying the physiological functions of MSCs can improve their application in regenerative medicine and increase our knowledge to better understand their biological behavior [16].

This review covers what is currently known about chicken MSCs. In its first part, we summarize knowledge about their sources, culture conditions, phenotype characterization, and differentiation. In the second part, we focus on the potential for MSCs to be used in three-dimensional (3D) culture and cell-to-cell interactions, their application as a feeder layer, their usefulness for meat production in vitro, their cryopreservation possibilities, and their usefulness in researching diseases in chickens (Figure 1).

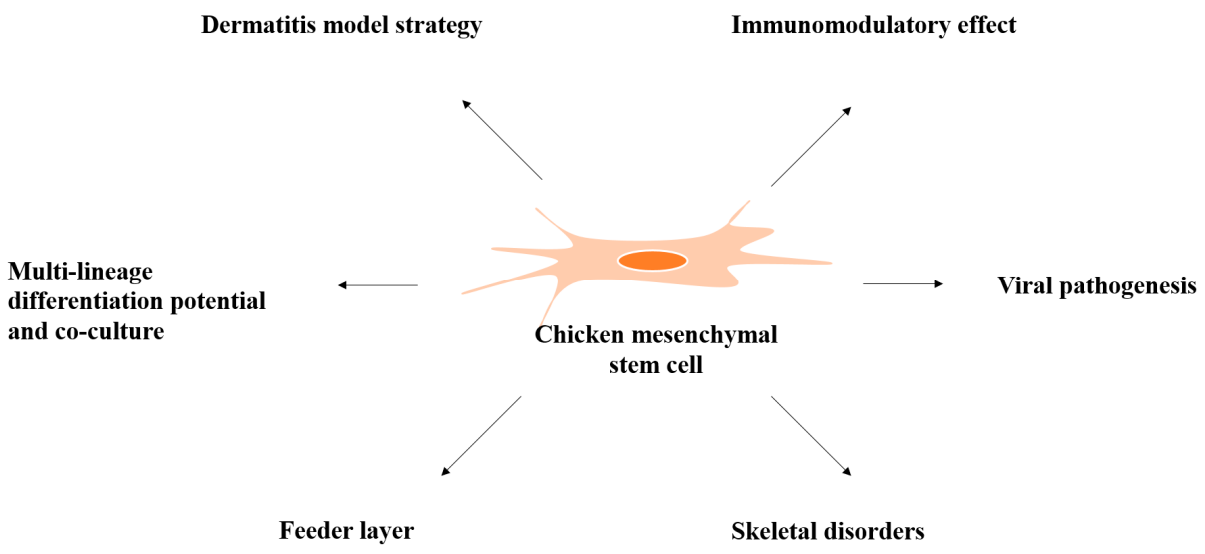

Figure 1. Multifunctional properties of chicken mesenchymal stem cells.

\section{Characterization of Chicken MSCs}

MSCs commonly are obtained where they were first discovered: from bone marrow as precursors for fibroblasts or stromal cells. An important part of MSC isolation is purification of samples from non-mesenchymal cell types such as hematopoietic and blood cells [17]. MSCs are usually aspirated from bone marrow (in which case they are termed bone marrowderived MSCs, or BM-MSCs) and then isolated by sieving for plastic adherence in vitro. In addition, MSCs can be obtained from compact bones [18], Wharton's jelly (WJ-MSCs) [19], and lung (L-MSCs) [20].

The key characteristics defining MSCs have been based on their capacity for colony formation, potential for self-renewal, expression of surface markers, and multi-lineage differentiation. The availability of stem cell-specific markers in poultry has limitations; therefore, researchers have to rely on reports of cell surface markers in mammalian species. Use of markers to verify MSC identity is an important control step to eliminate experimental variability and obtain a homogenous population of MSCs [18]. In mammals, MSCs express surface markers such as CD73, CD90, and CD105 [21-23] and transcription factors that include Oct4 [24], Nanog [25], and Sox2 [26], where PouV is a chicken homolog of mammalian Oct4 [27]. MSCs isolated from chicken bone marrow exhibit features similar to those of mammalian MSCs. Furthermore, lung MSCs in chicken and other mammalian 
species may help in understanding the pathogenesis of infectious and non-infectious lung diseases and the mechanisms of lung injury repair [13]. All chicken MSC characteristic parameters are summarized in the Table 1.

Table 1. Comparison of chicken MSCs derived from different sources.

\begin{tabular}{|c|c|c|c|c|c|c|c|c|}
\hline Sources & $\begin{array}{c}\text { Type of } \\
\text { Digestive }\end{array}$ & Separation & Morphology & Confluency & $\begin{array}{l}\text { Positive } \\
\text { Markers }\end{array}$ & $\begin{array}{l}\text { Negative } \\
\text { Markers }\end{array}$ & $\begin{array}{c}\text { Transcription } \\
\text { Factors }\end{array}$ & References \\
\hline \multirow[t]{2}{*}{$\begin{array}{c}\text { Bone } \\
\text { marrow }\end{array}$} & - & $\begin{array}{c}\text { Ficoll- } \\
\text { Hypaque } \\
(1.090 \mathrm{~g} / \mathrm{mL})\end{array}$ & $\begin{array}{l}\text { spindle- } \\
\text { shaped }\end{array}$ & 14 days & $\begin{array}{l}\text { CD44, CD90 } \\
\text { CD105 }\end{array}$ & $\mathrm{CD} 45$ & $\begin{array}{l}\text { PouV, Sox2, } \\
\text { Nanog }\end{array}$ & [17] \\
\hline & & $\begin{array}{c}\text { Percoll } \\
\text { solution } \\
(1.073 \mathrm{~g} / \mathrm{mL})\end{array}$ & $\begin{array}{l}\text { spindle- } \\
\text { shaped }\end{array}$ & $2-3$ days & $\begin{array}{l}\text { CD44, CD29, } \\
\text { CD71, CD73 }\end{array}$ & CD31, CD34 & & [19] \\
\hline $\begin{array}{l}\text { Compact } \\
\text { bones }\end{array}$ & $\begin{array}{c}0.25 \% \\
\text { collagenase }\end{array}$ & & $\begin{array}{l}\text { spindle- } \\
\text { shaped }\end{array}$ & 8-10 days & $\begin{array}{c}\text { CD90, } \\
\text { CD105, } \\
\text { CD73, CD44 }\end{array}$ & $\begin{array}{l}\text { CD31, CD34 } \\
\text { CD45 }\end{array}$ & & [18] \\
\hline \multirow[t]{2}{*}{ Lung } & $\begin{array}{c}0.1 \% \\
\text { collagenase }\end{array}$ & & $\begin{array}{l}\text { spindle- } \\
\text { shaped }\end{array}$ & 5-7 days & $\begin{array}{c}\text { CD29, CD73, } \\
\text { CD90, } \\
\text { CD105 }\end{array}$ & CD34, CD45 & OCT-4 & [20] \\
\hline & $\begin{array}{c}0.5 \mathrm{mg} / \mathrm{mL} \\
\text { collagenase } \\
\text { type IV }\end{array}$ & $\begin{array}{c}\text { Ficoll- } \\
\text { Hypaque } \\
(1.090 \mathrm{~g} / \mathrm{mL})\end{array}$ & $\begin{array}{l}\text { spindle- } \\
\text { shaped }\end{array}$ & 14 days & $\begin{array}{l}\text { CD44, CD90, } \\
\text { CD105 }\end{array}$ & & PouV & [28] \\
\hline $\begin{array}{l}\text { Wharton's } \\
\text { jelly }\end{array}$ & $\begin{array}{c}0.1 \% \\
\text { collagenase } \\
\text { type IV }\end{array}$ & & $\begin{array}{l}\text { fibroblast- } \\
\text { like } \\
\text { shaped }\end{array}$ & 5-6 days & $\begin{array}{l}\text { CD29, CD44, } \\
\text { CD71, CD73 }\end{array}$ & CD31, CD34 & & [29] \\
\hline
\end{tabular}

While specific surface markers are easily evaluable, a definition of MSCs can be completed by their abilities to differentiate into classic mesodermal lineages of bone, fat, and cartilage. Because MSCs have the ability to differentiate into osteocytes, chondrocytes, myocytes, and adipocytes, they constitute a suitable and predictable source of cells for purposes of regenerative therapy [30-34]. Supplements such as ascorbic acid and dexamethasone [35] at defined concentrations are able to direct MSCs toward osteogenic differentiation. For chondrogenic differentiation, TGF- $\beta 1$ often is used as an inducer [36].

The cells are stained using Alizarin Red and Von Kossa (VK) stains for determining mineralization and with alkaline phosphatase (ALP) [35] for detecting osteogenic differentiation at 7 and 14 days of treatment. Moreover, L-MSCs highly express the osteoblast-specific genes OPN and Col-1 in differentiated cells [20]. To stimulate adipogenesis, dexamethasone, indomethacin, insulin, and isobutylmethylxanthine are usually added to the cultures. After $96 \mathrm{~h}$ in culture in adipogenic media, Oil Red O is used to determine adipocyte induction. Adipogenic genes such as PPAR $\gamma, \mathrm{FABP} 2, \mathrm{c} / \mathrm{EBP} \alpha$, and $\mathrm{c} / \mathrm{EBP} \beta$ can be used for molecular detection of adipocyte differentiation $[18,19]$. Hydrocortisone and dexamethasone are well-established inducers of myogenesis. After $72 \mathrm{~h}$, myogenic gene expressions of MyoD, Pax7, Myf5, and myogenin are used in combination with quantitative reverse transcription polymerase chain reaction for detecting myogenesis $[18,19]$. Vascular endothelial growth factor (VEGF), basic fibroblast growth factor (bFGF), and insulin-like growth factor (IGF-1) are used for endothelial induction, and endothelial markers such as CD34 and CD31 are used for its determination [19]. Moreover, neurogenic differentiation is induced by addition of glial cell-derived neurotrophic factor. Wang et al. (2018) [20] established that nestin and MAP-2, the markers of neural cells, are highly expressed in differentiated L-MSCs. Supplements such as antibiotics and growth factors can affect the phenotypic properties of MSCs and their multi-lineage potential.

MSCs are able to also influence functions of such major immune cells as dendritic cells, T cells, B cells, and natural killer (NK) cells. Although the immunomodulatory mechanism of MSCs is not yet fully understood, there are some mechanisms by which MSCs can be influenced. High levels of pro-inflammatory cytokines can activate MSCs to produce immunosuppressive cytokines, chemokines, as well as nitric oxide (NO) [37]. 
$\mathrm{NO}$ is one of the factors that can suppress $\mathrm{T}$ cell proliferation. Moreover, it has been noted that MSCs and macrophages also suppress T cell proliferation via NO inhibition of Stat5 phosphorylation $[38,39]$, and the production of NO during MSC differentiation into chondrocytes has been observed. MSCs have typical in vitro modulatory functions, such as to inhibit T cell and B cell proliferation, as well as DCs differentiation $[40,41]$, thereby resulting in inhibition of immune responses both in vitro and in vivo. Cytokines and growth factors are specific modulators by which MSCs can influence inflammatory responses. This makes MSCs a very promising tool for immunomodulatory cell therapy in immune-mediated diseases. $T$ cells are characterized by the effect of cell proliferation and cytokine secretion. MSC inhibition of T cell proliferation is especially important for immune homeostasis and self-tolerance maintenance [42]. Like mammalian MSCs, chicken MSCs also have immunoregulatory function and inhibit in vitro the mitogenic response of $\mathrm{T}$ cells. In chickens, a correlation between $\mathrm{NO}$ production and $\mathrm{T}$ cell suppression in coculture with MSCs has been noted. Nevertheless, the role of NO in the MSC and T cell coculture system remains unknown.

This review now directs its focus to chickens as a model platform for application of available techniques previously used in other animals that can expand and enrich our knowledge in the area of avian research.

\section{Biological Properties of Chicken MSCs}

\subsection{Three-Dimensional (3D) Culture and MSC Interactions}

Hematopoietic progenitor/stem cells (HPCs/HSCs), MSCs, and multiple elements of the extracellular matrix are components belonging to the microenvironment. It has been noted that MSCs play a crucial role in HPC/HSC function and self-renewal [43,44]. In a study [45] involving the 3D collagen-based culture model, MSCs were used in coculture with HPCs/HSCs. In another study, a significant effect of BM-MSCs upon HPCs/HSCs in terms of self-renewal, maintenance, and differentiation was recorded [46]. BM-MSCs are used as stromal cells for coculture with HPCs/HSCs obtained from umbilical cord blood, and WJ-MSCs are applied as stromal support for HSCs. BM-MSCs in coculture with HPCs/HSCs using the 3D-culture system enable HPC/HSC expansion and regulation of the hematopoiesis process [45]. Study [45] also observed fibronectin production by BM-MSCs to support synthesis of collagen type I and production of osteopontin, which is important for osteogenic differentiation. Moreover, HPCs in the collagen gel containing MSCs revealed initial differentiation into the myeloid lineage, as proven by positivity for CD45. This differentiation was shown by comparison to stromal-cell free conditions as previously described [47].

On the whole, MSCs constitute a promising tool for cellular modulation by secretion and interaction of appropriate molecules to improve regeneration processes in many types of tissues. There are available today many scaffolds, such as micro-/nano- electrospun (EFs) fibers $[48,49]$ or polycaprolactone (PCL) EFs, that modulate paracrine signaling to support cell attachment, proliferation, as well as maintenance of cell stemness and pluripotency [50]. Based on these findings, 3D culture can be used to study the effects of various substances in coculture with MSCs also in chickens in order to better understand the interactions and substitute for the natural environment.

\subsection{Feeder Cells Layer}

Primordial germ cells (PGCs) are progenitors of germ cells, and they have important roles in spermatozoa and egg formation in the adult organism [51]. The most commonly used feeder cells for PGCs culture are xeno-animal buffalo rat liver (BRL) cells, Sandoz inbred mouse-derived thioguanine-resistant and ouabain-resistant (STO) cells, or mouse embryonic fibroblast (MEF) cells, but these cells have their limitations, as contamination of various types can disturb the potential of PGCs. PGC proliferation in vitro depends upon the feeder cells having a powerful capacity to proliferate and secrete cytokines [52,53]. The authors [54] reported that feeder cells can promote proliferation of circulating blood 
PGCs (cPGCs) and gonadal PGCs (gPGCs) in vitro and that they have the characteristics of an effective feeder layer. Several studies have shown that an MSC-feeder layer ensures all conditions for human-induced pluripotent stem cell (hiPSC), human embryonic stem cell (hESC), and mouse embryonic stem cell (mESC) proliferation and expansion and, moreover, while maintaining cell pluripotency [55-57]. MSCs have potential as a feeder cell layer in vitro to provide for expansion of chicken PGCs [54]. Further research is needed to analyze the potential interactions of MSCs via MSC-secreted cytokines with the different chicken cell types.

\subsection{Infectious Bursal Disease Virus}

Poultry are surrounded today by numerous bacterial and viral agents [58]. Infectious bursal disease virus (IBDV), also known as Gumboro disease, was first observed about 60 years ago as an immunosuppressive disorder in young chickens. This virus infects the bursa of Fabricius in young chickens at early ages, and a subclinical form of infection occurs in older birds [59]. The infection leads to morbidity, mortality, and immunosuppression [60]. In vivo presence of IBDV has been detected in several tissues, including bone marrow $[61,62]$. It is known that MSCs are important cells with the ability to support hematopoiesis and modulate differentiation of hematopoietic stem cells via the expression of cell adhesion molecules necessary for cell-to-cell interactions that result in cytokine and growth factor release [59]. Different types of immune cells are able to modify the host response to IBDV through release of cytokines such as interferon (IFN)- $\alpha$ and IFN$\gamma$ [63-67] and pro-inflammatory cytokines such as interleukin (IL)-2 [64,65], IL-18 [65], and IL-6 [65,66]. Inasmuch as the virus does not proliferate in chicken fibroblast cells [68], it therefore can be hypothesized that MSCs could also be a target for IBDV infection. In study [13] they discovered an interaction between IBDV and MSCs. Because MSCs participate in the regulation of hematopoietic precursor differentiation and proliferation, examining these interactions can contribute to better understanding of the virus's pathogenesis. Moreover, we believe that such stem cells or cell-based vaccines will provide a promising platform or strategy for controlling IBDV and other viruses (zoonoses) with unknown potential risk as a means of preventing potential pandemic diseases.

\subsection{Skeletal Diseases}

Vitamin D3, calcitriol (1,25-(OH)2D3), plays an important role as a nutritional factor relevant to poultry bone strength [69]. Differences between birds and mammals in the formation of the long bones relate to dietary aspects and metabolic activity of 1,25-(OH)2D3. Specifically, avian species have long bone development without secondary ossification until hatching. Ossification only occurs in the proximal and distal ends of the tibiotarsus and tarsometatarsus [70]. The calcium (Ca) level in blood increases the bone strength, and vitamin $\mathrm{D}$ facilitates $\mathrm{Ca}$ absorption. Therefore, dietary supplementation with adequate Ca and vitamin D is important. It is known that egg laying causes large Ca losses, and so it is necessary to supplement vitamin D to maintain optimal bone structure in laying hens. Tibial dyschondroplasia (TD) is a skeletal disorder in growing chickens characterized by an avascular and non-mineralized growth plate that can lead to deformed tibial bone and lameness [71]. Mineral deficiencies in the diet, and especially insufficient supply of $\mathrm{Ca}$, also can cause keel bone fracture [72-77]. Stimulatory effects of 1,25-(OH)2D3 on osteogenic differentiation and mineralization have been recorded in humans [78-81], in rat osteoblasts [82,83], in mouse osteoblasts [84-87], and in chicken osteoblasts [88,89]. The amount of an administered substance is important, however, due to the possibility of negative effects. Because MSCs have the abilities for self-renewal and multi-lineage differentiation to osteogenic lineages, they can be used in the study of mineralization during osteogenesis. Vitamin D3 is related to immunoregulation, anti-oxidation, anticancer actions, cardiovascular benefits, and such aspects of bone development as osteogenic differentiation and mineralization [89]. Available data suggest that administration of 1,25$(\mathrm{OH}) 2 \mathrm{D} 3$ is important for optimizing bone health in the poultry industry and that avian 
BM-MSCs constitute a useful tool for examining underlying effects [90]. As we also know, poultry and pig meats have shown the greatest consumption increases [91], and poultry meat consumption has increased in all regions of the world [92].

\subsection{Probiotics and Prebiotics}

Antibiotic growth promoters (AGPs) are widely used in protecting poultry against pathogens and disease and improving growth performance. Prolonged administration of AGPs, however, can lead to bacterial resistance and result in drug residues in poultry products as well as a prohibition against using antibiotics in poultry production. Therefore, it is necessary to develop an alternative pathway for improving production [93].

The chicken gastrointestinal tract is home to a population of microorganisms living in symbiotic relationship with their host, and this relationship is important for the host's nutrition, metabolism, and immunity-indeed its homeostasis. Although the intestinal microbial environment in adult chickens is highly stable, it can be influenced by feed or stress. One of the major causes of deterioration in meat quality relates to interactions between macronutrients and medications [94].

Live microbial feed supplements known as probiotics, such as Lactobacillus, Bifidobacterium, or yeasts [95], can confer health benefits to the host. On the other hand, prebiotics, which are non-digestible food ingredients, can enhance lipid metabolism and support polyunsaturated fatty acid levels in chicken meat [96] while resulting in increased levels of health-promoting bacteria within the intestinal tract. Administration of probiotics and prebiotics in feed can improve a flock's immunity by reducing harmful microbes in the intestine and thus the need for antibiotics $[20,93]$. Although the efficacy of probiotics and prebiotics in poultry has not yet been sufficiently studied, it is known that MSCs interact with a wide range of intestinal bacteria having significant effects on MSC function [97,98]. MSCs have the ability to home and engraft in the lamina propria of the gastrointestinal tract during intestinal inflammation and exert potent immunomodulatory functions [99]. From this point of view, therefore, it would be pertinent to analyze in vitro interactions between MSCs isolated from AGP-treated animals and applied pro- and prebiotics in order to assess the MSCs profile in terms of, for example, viability, immunomodulatory properties, and values of inflammatory cytokines. With this in mind, the studies would progress to examining the possible effects of pro- and prebiotics on MSC physiology as a possible future replacement for AGPs.

\subsection{Chicken Dermatitis}

Gangrenous dermatitis (GD) is a disorder that affects broiler chickens and results in economic losses in the poultry industry worldwide [100]. GD is primarily caused by the Gram-positive anaerobic bacilli Clostridium perfringens type A [101-104], Clostridium septicum, and Staphylococcus aureus [105]. The disease is characterized by hemorrhage, congestion, and necrosis of the skin as indicated by edema. The breast, abdomen, back, thighs, tail, and wings are the most significantly affected body areas [106]. The dermatitis results in lower meat quality [107]. Typical symptoms of GD are poor appetite, decreased muscle coordination, skin edema, leg weakness, and ultimately crepitus [108]. GD in chickens causes decreased splenocyte proliferation in response to concanavalin A (Con A) or lipopolysaccharide (LPS); greater levels of serum NO and a-1-acid glycoprotein (a-1-AGP); higher levels of T cells, B cells, and macrophages; as well as increased levels of transcripts encoding IL-8, IFN-a, TNFSF-15, and LITAF compared with GD-free chickens [94]. Therefore, MSCs can be useful in evaluating a variety of diseases, including mainly tissue-related and immune-mediated diseases, due to their ability to modulate the innate and adaptive immune systems. Several experimental models have been used to clarify the role of C. septicum, C. perfringens, and S. aureus in the pathogenesis of GD in vivo [109], but MSC coculture in vitro with the aforementioned pathogens can be a promising approach for assessing their interactions as well as their immunomodulatory properties. 


\subsection{Meat "In Vitro"}

Nowadays, meat production is the major source of pollution. World meat production contributes between 15 and $24 \%$ of greenhouse gas emissions [110]. It is known that chicken meat production requires $3,918 \mathrm{~m}^{3} /$ ton of water [111]. Therefore, satisfying the demand for meat in the future will be a challenge when we intend on maximizing the use of agricultural sources and reducing the greenhouse gas production. Meat worldwide consumption was calculated by Fiala [112], who predicts a 72\% increase in meat production in 2030 compared to 2000. The 1918 H1N1 Spanish Influenza pandemic [113] as well as SARS-CoV-2 are of utmost concern as they have spread to almost all countries and killed thousands of people worldwide [114]. The correlation between meat production and outbreaks of diseases cannot be overlooked.

In vitro meat culturing seems to be a suitable substitution for conventional meat production. In vitro cultured meat from stem cells in controlled culture and physiological conditions in the laboratory uses MSCs that are able to differentiate to myocyte or induced pluripotent stem cells (iPSCs) by genome reprogramming of somatic cells [115]. In vitro meat culturing has many advantages: (a) in vitro cultivation is faster than growth, (b) the impact of cultivation on the environment is lower, and (c) muscle tissue is cultivated without affecting the skeleton [116]; moreover, cultured meat is a healthier, cleaner, and disease-free animal protein source compared to commercial farming [117] (Figure 2).

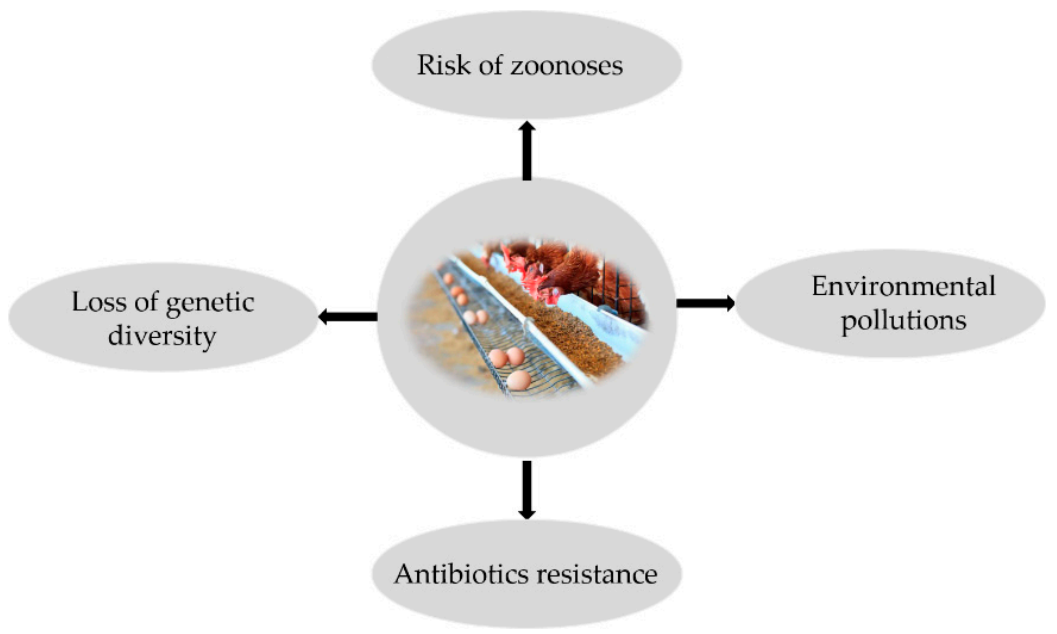

Figure 2. Disadvantages of commercial farming of livestock.

Cell culture also involves scaffold-based cell and tissue approaches relying on the isolation, culture, and differentiation into myoblasts. However, there is possibility to coculture stem cells with adipocytes, which support them to differentiate, and then form myofibers [118]. However, cell culture requires many growth factors such as IGF, bFGF, HGF, Wnt3a, and Wnt7a to promote differentiation into myotubes and myofibers [119]. Moreover, scaffolds have an important role in the cell culture-based approach for in vitro meat production. Scaffolds are commonly made of natural and edible polymeric biomaterials such as collagen that allow $3 \mathrm{D}$ tissue culture and subsequent complex structuring of synthetic meat $[120,121]$.

We believe that this transformation in the farm process will be inevitable. Moreover, this technology offers an opportunity for non-meat eaters because this meat is safe and free from animal slaughtering and cruelty. Since in vitro production is controlled, it is feasible to alter high-quality meat production on a sustainable basis. From this point of view, extra embryonic and adult MSCs could be navigated toward myocyte differentiation, which ultimately forms myotubes and are, thus, suggested as a potential starting point for in vitro chicken meat production. 


\subsection{Cryopreservation}

In recent years, several animal stem cell banks have been established worldwide. Although these banks are not used for therapeutic purposes, they are considered a promising way for the storage of animal genetic resources [108]. For this reason, we have noticed the increased demand for national gene banks to preserve either native or worldwide biodiversity. These banks preserve genetic information from many important (already endangered) livestock species. However, in addition to embryos and gametes, adult stem cells also represent a significant genetic resource that can be obtained from various biological sources.

The stem cell banks also give a source of stem cell lines that have high quality and safety standards [122]. Many animal embryonic and adult stem cell lines have been made and cryopreserved, including primordial, bone marrow mesenchymal, neural, cardiac, endothelial, adipose, and umbilical cord mesenchymal stem cells [123,124]. Biological research could use the method of cryopreservation of stem cells in other fields as well, as it has already given promising results [123]. Cryopreservation of stem cells is important to provide storage of high cell numbers, fast transport, and to preserve cells for long periods. Due to the increased level of endangered animals, it is important to preserve genetic material for future applications.

The chicken was the first farm animal with a completely sequenced genome. Because of its in ovo embryonic development rather than in utero, the chicken is a suitable model for embryology and development studies. The chicken provides a model organism for the study of cancer and viruses. The first tumor virus and oncogene (src), Rous sarcoma virus, was identified in the chicken. The immune system of chickens provides the first indication of the distinctions between $\mathrm{T}$ and $\mathrm{B}$ cells, with the B-cell based avian bursa of Fabricius [125]. Therefore, the chicken is an important model for evolution, embryology, cell biology, immunology, virology, oncology, and gene regulation studies. From this point of view, it is also important to cryopreserve MSCs for subsequent assessment of MSCs in vitro and further usage in the future (e.g., iPSCs).

\section{Conclusions}

This review has emphasized the importance of chicken MSCs for their self-renewal potential and multi-lineage differentiation as well as current knowledge concerning their usefulness for examining pathogenic potential of infectious bursal disease virus, studying mineralization during osteogenesis, and using MSCs as a feeder layer. MSCs also constitute a very promising tool for immunomodulatory cell therapy in immune-mediated diseases due to their inhibition effect on T cell proliferation via NO production. Moreover, MSCbased treatment could be a model strategy in studying chicken dermatitis disorders as well as for reducing the need to administer AGPs. Next, BM-MSCs in coculture with hematopoietic progenitor/stem cells can provide expansion and regulation of the hematopoiesis process using the 3D-culture system for future research in chickens. Finally, current meat production methods are associated with many problems such as animal welfare issues, risk of infectious diseases, biodiversity loss, and environmental pollution. Therefore, MSCs provide an alternative way to eliminate these problems using in vitro meat culturing. Based on these findings, we may conclude that MSCs can provide a useful model in the field of chicken stem cell research.

Author Contributions: Conceptualization, A.S. and V.Z.; formal analysis, P.S.; investigation, A.S. and P.S.; writing — original draft preparation, A.S.; writing — review and editing, V.Z., E.V. and P.S.; visualization, P.S.; supervision, P.S.; project administration, P.S.; funding acquisition, P.S. All authors have read and agreed to the published version of the manuscript.

Funding: This research was funded by the Technology Agency of the Czech Republic (TJ04000511). Institutional Review Board Statement: Not applicable.

Data Availability Statement: No new data were created or analyzed in this study.

Conflicts of Interest: The authors declare no conflict of interest. 


\section{References}

1. Mir, N.A.; Rafiq, A.; Kumar, F.; Singh, V.; Shukla, V. Determinants of broiler chicken meat quality and factors affecting them: A review. J. Food Sci. Technol. 2017, 54, 2997-3009. [CrossRef] [PubMed]

2. Fornari, M.B.; Zanella, R.; Ibelli, A.M.; Fernandes, L.T.; Cantão, M.E.; Thomaz-Soccol, V.; Ledur, M.C.; Peixoto, J.O. Unraveling the associations of osteoprotegerin gene with production traits in a paternal broiler line. SpringerPlus 2014, 3, 1-8. [CrossRef]

3. Prockop, D.J. Marrow stromal cells as stem cells for nonhematopoietic tissues. Science 1997, 276, 71-74. [CrossRef]

4. Crigler, L.; Kazhanie, A.; Yoon, T.J.; Zakhari, J.; Anders, J.; Taylor, B.; Virador, V.M. Isolation of a mesenchymal cell population from murine dermis that contains progenitors of multiple cell lineages. FASEB J. 2007, 21, 2050-2063. [CrossRef] [PubMed]

5. Dumas, A.; Le Drévo, M.A.; Moreau, M.F.; Guillet, C.; Baslé, M.F.; Chappard, D. Isolation of osteoprogenitors from murine bone marrow by selection of CD11b negative cells. Cytotechnology 2008, 58, 163. [CrossRef]

6. Kar, S.; Mitra, S.; Banerjee, E.R. Isolation and culture of embryonic stem cells, mesenchymal stem cells, and dendritic cells from humans and mice. Methods. Mol. Biol. 2015, 1516, 145-152. [CrossRef]

7. Kumar, K.; Agarwal, P.; Das, K.; Mili, B.; Madhusoodan, A.P.; Kumar, A.; Bag, S. Isolation and characterization of mesenchymal stem cells from caprine umbilical cord tissue matrix. Tissue Cell 2016, 48, 653-658. [CrossRef]

8. Li, H.; Ghazanfari, R.; Zacharaki, D.; Lim, H.C.; Scheding, S. Isolation and characterization of primary bone marrow mesenchymal stromal cells. Ann. N. Y. Acad. Sci. 2016, 1370, 109-118. [CrossRef]

9. Krešić, N.; Šimić, I.; Lojkić, I.; Bedeković, T. Canine adipose derived mesenchymal stem cells transcriptome composition alterations: A step towards standardizing therapeutic. Stem Cells Int. 2017. [CrossRef]

10. Nakamura, M.; Nishida, H.; Yoshizaki, K.; Akiyoshi, H.; Hatoya, S.; Sugiura, K.; Inaba, T. Canine mesenchymal stromal cell-conditioned medium promotes survival and neurite outgrowth of neural stem cells. J. Vet. Med. Sci. 2020. [CrossRef]

11. Munoz, J.L.; Greco, S.J.; Patel, S.A.; Sherman, L.S.; Bhatt, S.; Bhatt, R.S.; Shrensel, J.A.; Guan, Y.Z.; Xie, G.; Ye, J.H.; et al. Feline bone marrow-derived mesenchymal stromal cells (MSCs) show similar phenotype and functions with regards to neuronal differentiation as human MSCs. Differentiation 2012, 84, 214-222. [CrossRef] [PubMed]

12. Dominici, M.L.B.K.; Le Blanc, K.; Mueller, I.; Slaper-Cortenbach, I.; Marini, F.C.; Krause, D.S.; Horwitz, E.M. Minimal criteria for defining multipotent mesenchymal stromal cells. The International Society for Cellular Therapy position statement. Cytotherapy 2006, 8, 315-317. [CrossRef]

13. Majumdar, M.K.; Thiede, M.A.; Mosca, J.D.; Moorman, M.; Gerson, S.L. Phenotypic and functional comparison of cultures of marrow-derived mesenchymal stem cells (MSCs) and stromal cells. J. Cell. Physiol. 1998, 176, 57-66. [CrossRef]

14. Eleuteri, S.; Fierabracci, A. Insights into the secretome of mesenchymal stem cells and its potential applications. Inter. J. Mol. Sci. 2020, 20, 4597. [CrossRef]

15. Fu, X.; Liu, G.; Halim, A.; Ju, Y.; Luo, Q.; Song, G. Mesenchymal stem cell migration and tissue repair. Cells 2019, 8, 784. [CrossRef]

16. Zannetti, A.; Benga, G.; Brunetti, A.; Napolitano, F.; Avallone, L.; Pelagalli, A. Role of Aquaporins in the Physiological Functions of Mesenchymal Stem Cells. Cells 2020, 9, 2678. [CrossRef] [PubMed]

17. Khatri, M.; Sharma, J.M. Susceptibility of chicken mesenchymal stem cells to infectious bursal disease virus. J. Virol. Methods. 2009, 160, 197-199. [CrossRef] [PubMed]

18. Adhikari, R.; Chen, C.; Waters, E.; West, F.D.; Kim, W.K. Isolation and differentiation of mesenchymal stem cells from broiler chicken compact bones. Front. Physiol. 2019, 9, 1892. [CrossRef] [PubMed]

19. Bai, C.; Hou, L.; Ma, Y.; Chen, L.; Zhang, M.; Guan, W. Isolation and characterization of mesenchymal stem cells from chicken bone marrow. Cell Tissue Bank. 2013, 14, 437-451. [CrossRef]

20. Wang, X.; Wang, J.J.; Ji, H.; Guan, W.; Zhao, Y. Isolation, culture, and characterization of chicken lung-derived mesenchymal stem cells. Can. J. Vet. Res. 2018, 82, 225-235.

21. Teresa Conconi, M.; Di Liddo, R.; Tommasini, M.; Calore, C.; Paolo Parnigotto, P. Phenotype and differentiation potential of stromal populations obtained from various zones of human umbilical cord: An overview. J. Tissue Eng. Regen. Med. 2011, 4, 6-20. [CrossRef]

22. Lin, C.S.; Xin, Z.C.; Dai, J.; Lue, T.F. Commonly used mesenchymal stem cell markers and tracking labels: Limitations and challenges. Histol. Histopathol. 2013, 28, 1109. [CrossRef]

23. Cruz, F.F.; Rocco, P.R.M. The potential of mesenchymal stem cell therapy for chronic lung disease. Expert. Rev. Respir. Med. 2020, 14, 31-39. [CrossRef] [PubMed]

24. Nichols, J.; Zevnik, B.; Anastassiadis, K.; Niwa, H.; Klewe-Nebenius, D.; Chambers, I.; Schöler, H.; Smith, A. Formation of pluripotent stem cells in the mammalian embryo depends on the POU transcription factor Oct4. Cell 1998, 95, 379-391. [CrossRef]

25. Chambers, I.; Colby, D.; Robertson, M.; Nichols, J.; Lee, S.; Tweedie, S.; Smith, A. Functional expression cloning of Nanog, a pluripotency sustaining factor in embryonic stem cells. Cell 2003, 113, 643-655. [CrossRef]

26. Avilion, A.A.; Nicolis, S.K.; Pevny, L.H.; Perez, L.; Vivian, N.; Lovell-Badge, R. Multipotent cell lineages in early mouse development depend on SOX2 function. Genes Dev. 2003, 17, 126-140. [CrossRef]

27. Lavial, F.; Acloque, H.; Bertocchini, F.; MacLeod, D.J.; Boast, S.; Bachelard, E.; Montillet, G.; Thenot, S.; Sang, H.M.; Stern, C.D.; et al. The Oct4 homologue PouV and Nanog regulate pluripotency in chicken embryonic stem cells. Development 2007, 134, 3549-3563. [CrossRef] [PubMed]

28. Khatri, M.; O’Brien, T.D.; Goyal, S.M.; Sharma, J.M. Isolation and characterization of chicken lung mesenchymal stromal cells and their susceptibility to avian influenza virus. Dev. Comp. Immunol. 2010, 34, 474-479. [CrossRef] 
29. Bai, C.; Li, X.; Hou, L.; Zhang, M.; Guan, W.; Ma, Y. Biological characterization of chicken mesenchymal stem/progenitor cells from umbilical cord Wharton's jelly. Mol. Cell. Biochem. 2013, 376, 95-102. [CrossRef] [PubMed]

30. Krampera, M.; Glennie, S.; Dyson, J.; Scott, D.; Laylor, R.; Simpson, E.; Dazzi, F. Bone marrow mesenchymal stem cells inhibit the response of naive and memory antigen-specific T cells to their cognate peptide. Blood 2003, 101, 3722-3729. [CrossRef]

31. Maitra, B.; Szekely, E.; Gjini, K.; Laughlin, M.J.; Dennis, J.; Haynesworth, S.E.; Koç, O.N. Human mesenchymal stem cells support unrelated donor hematopoietic stem cells and suppress T-cell activation. Bone Marrow Transplant. 2004, 33, 597-604. [CrossRef] [PubMed]

32. Beyth, S.; Borovsky, Z.; Mevorach, D.; Liebergall, M.; Gazit, Z.; Aslan, G.E.; Rachmilewitz, J. Human mesenchymal stem cells alter antigen-presenting cell maturation and induce T-cell unresponsiveness. Blood 2005, 105, 2214-2219. [CrossRef]

33. Groh, M.E.; Maitra, B.; Szekely, E.; Koç, O.N. Human mesenchymal stem cells require monocyte-mediated activation to suppress alloreactive T cells. Ex. Hematol. 2005, 33, 928-934. [CrossRef] [PubMed]

34. Meisel, R.; Zibert, A.; Laryea, M.; Göbel, U.; Däubener, W.; Dilloo, D. Human bone marrow stromal cells inhibit allogeneic T-cell responses by indoleamine 2, 3-dioxygenase-mediated tryptophan degradation. Blood 2004, 103, 4619-4621. [CrossRef] [PubMed]

35. Parhami, F.; Morrow, A.D.; Balucan, J.; Leitinger, N.; Watson, A.D.; Tintut, Y.; Berliner, J.A.; Demer, L.L. Lipid oxidation products have opposite effects on calcifying vascular cell and bone cell differentiation: A possible explanation for the paradox of arterial calcification in osteoporotic patients. Arterioscler. Tthromb. Vasc. Biol. 1997, 17, 680-687. [CrossRef]

36. Kocamaz, E.; Gok, D.; Cetinkaya, A.; Tufan, A.C. Implication of C-type natriuretic peptide-3 signaling in glycosaminoglycan synthesis and chondrocyte hypertrophy during TGF- $\beta 1$ induced chondrogenic differentiation of chicken bone marrow-derived mesenchymal stem cells. J. Mol. His. 2012, 43, 497-508. [CrossRef]

37. Kyurkchiev, D.; Bochev, I.; Ivanova-Todorova, E.; Mourdjeva, M.; Oreshkova, T.; Belemezova, K.; Belemezova, K.; Kyurkchiev, S. Secretion of immunoregulatory cytokines by mesenchymal stem cells. World J. Stem Cells 2014, 6, 552-570. [CrossRef]

38. Mazzoni, A.; Bronte, V.; Visintin, A.; Spitzer, J.H.; Apolloni, E.; Serafini, P.; Zanovello, P.; Segal, D.M. Myeloid suppressor lines inhibit $\mathrm{T}$ cell responses by an NO-dependent mechanism. J. Immunol. 2002, 168, 689-695. [CrossRef]

39. Mais, A.; Klein, T.; Ullrich, V.; Schudt, C.; Lauer, G. Prostanoid pattern and iNOS expression during chondrogenic differentiation of human mesenchymal stem cells. J. Cell. Biochem. 2006, 98, 798-809. [CrossRef]

40. Glennie, S.; Soeiro, I.; Dyson, P.J.; Lam, E.W.F.; Dazzi, F. Bone marrow mesenchymal stem cells induce division arrest anergy of activated T cells. Blood 2005, 105, 2821-2827. [CrossRef]

41. Corcione, A.; Benvenuto, F.; Ferretti, E.; Giunti, D.; Cappiello, V.; Cazzanti, F.; Risso, M.; Gualandi, F.; Luigi, G.; Pistoia, M.V.; et al. Human mesenchymal stem cells modulate B-cell functions. Blood 2006, 107, 367-372. [CrossRef]

42. Djouad, F.; Plence, P.; Bony, C.; Tropel, P.; Apparailly, F.; Sany, J.; Jorgensen, C. Immunosuppressive effect of mesenchymal stem cells favors tumor growth in allogeneic animals. Blood 2003, 102, 3837-3844. [CrossRef] [PubMed]

43. Adams, G.B.; Scadden, D.T. The hematopoietic stem cell in its place. Nat. Immunol. 2006, 7, 333-337. [CrossRef] [PubMed]

44. Wagner, W.; Roderburg, C.; Wein, F.; Diehlmann, A.; Frankhauser, M.; Schubert, R.; Eckstein, V.; Ho, A.D. Molecular and secretory profiles of human mesenchymal stromal cells and their abilities to maintain primitive hematopoietic progenitors. Stem Cells 2007, 25, 2638-2647. [CrossRef] [PubMed]

45. Leisten, I.; Kramann, R.; Ferreira, M.S.V.; Bovi, M.; Neuss, S.; Ziegler, P.; Wagner, W.; Knüchel, R.; Schneider, R.K. 3D co-culture of hematopoietic stem and progenitor cells and mesenchymal stem cells in collagen scaffolds as a model of the hematopoietic niche. Biomaterials 2012, 33, 1736-1747. [CrossRef] [PubMed]

46. Walenda, T.; Bokermann, G.; Ferreira, M.S.V.; Piroth, D.M.; Hieronymus, T.; Neuss, S.; Zenke, M.; Ho, A.D.; Müller, A.M.; Wagner, W. Synergistic effects of growth factors and mesenchymal stromal cells for expansion of hematopoietic stem and progenitor cells. Exp. Hematol. 2011, 39, 617-628. [CrossRef] [PubMed]

47. Walenda, T.; Bork, S.; Horn, P.; Wein, F.; Saffrich, R.; Diehlmann, A.; Eckstein, V.; Ho, A.D.; Wagner, W. Co-culture with mesenchymal stromal cells increases proliferation and maintenance of haematopoietic progenitor cells. J. Cell Mol. Med. 2010, 14, 337-350. [CrossRef]

48. Rustad, K.C.; Wong, V.W.; Sorkin, M.; Glotzbach, J.P.; Major, M.R.; Rajadas, J.; Longaker, M.T.; Gurtner, G.C. Enhancement of mesenchymal stem cell angiogenic capacity and stemness by a biomimetic hydrogel scaffold. Biomaterials 2012, 33, 80-90. [CrossRef] [PubMed]

49. Li, Z.; Tian, X.; Yuan, Y.; Song, Z.; Zhang, L.; Wang, X.; Li, T. Effect of cell culture using chitosan membranes on stemness marker genes in mesenchymal stem cells. Mol. Med. Rep. 2013, 7, 1945-1949. [CrossRef]

50. Su, N.; Gao, P.L.; Wang, K.; Wang, J.Y.; Zhong, Y.; Luo, Y. Fibrous scaffolds potentiate the paracrine function of mesenchymal stem cells: A new dimension in cell-material interaction. Biomaterials 2017, 141, 74-85. [CrossRef]

51. Qian, C.; Zhou, Z.; Han, H.; Zhao, C.; Jin, X.; Zhao, H.; Zhang, Y.; Chen, W.; Yang, N.; Li, Z. Influence of microgravity on the concentration of circulating primordial germ cells in Silky chicken offspring. J. Poult. Sci. 2009, 47, 65-70. [CrossRef]

52. Naeemipour, M.; Dehghani, H.; Bassami, M.; Bahrami, A. Expression dynamics of pluripotency genes in chicken primordial germ cells before and after colonization of the genital ridges. Mol. Reprod. Dev. 2013, 80, 849-861. [CrossRef]

53. Tonus, C.; Cloquette, K.; Ectors, F.; Piret, J.; Gillet, L.; Antoine, N.; Grobet, L. Long term-cultured and cryopreserved primordial germ cells from various chicken breeds retain high proliferative potential and gonadal colonisation competency. Reprod. Fertil. Dev. 2016, 28, 628-639. [CrossRef] 
54. Li, D.; Chen, Z.; Chen, S.; Ji, H.; Zhan, X.; Luo, D.; Luo, H.; Wang, B. Chicken Mesenchymal Stem Cells as Feeder Cells Facilitate the Cultivation of Primordial Germ Cells from Circulating Blood and Gonadal Ridge. Stem Cell Discov. 2019, 9, 1-14. [CrossRef]

55. Xie, H.; Sun, L.; Zhang, L.; Liu, T.; Chen, L.; Zhao, A.; Gao, F.; Zou, P.; Li, Q.; Guo, A.J.; et al. Mesenchymal stem cell-derived microvesicles support ex vivo expansion of cord blood-derived CD34+ cells. Stem Cells 2016. [CrossRef]

56. Iacono, M.L.; Anzalone, R.; La Rocca, G.; Baiamonte, E.; Maggio, A.; Acuto, S. Wharton's jelly mesenchymal stromal cells as a feeder layer for the ex vivo expansion of hematopoietic stem and progenitor cells: A review. Stem. Cell. Rev. Rep. 2017, 13, 35-49. [CrossRef]

57. Chang, Y.H.; Chu, T.Y.; Ding, D.C. WNT/ $\beta$-Catenin signaling pathway regulates non-tumorigenesis of human embryonic stem cells co-cultured with human umbilical cord mesenchymal stem cells. Sci. Rep. 2017, 7, 1-10. [CrossRef] [PubMed]

58. Zmrhal, V.; Slama, P. Current knowledge about interactions between avian dendritic cells and poultry pathogens. Dev. Comp. Immunol. 2020, 104, 103565. [CrossRef] [PubMed]

59. Tippenhauer, M.; Heller, D.E.; Weigend, S.; Rautenschlein, S. The host genotype influences infectious bursal disease virus pathogenesis in chickens by modulation of T cells responses and cytokine gene expression. Dev. Comp. Immunol. 2013, 40, 1-10. [CrossRef] [PubMed]

60. Dey, S.; Pathak, D.C.; Ramamurthy, N.; Maity, H.K.; Chellappa, M.M. Infectious bursal disease virus in chickens: Prevalence, impact, and management strategies. Vet. Med. Res. Rep. 2019, 10, 85. [CrossRef] [PubMed]

61. Elankumaran, S.; Heckert, R.A.; Moura, L. Pathogenesis and tissue distribution of a variant strain of infectious bursal disease virus in commercial broiler chickens. Avian Dis. 2002, 46, 169-176. [CrossRef]

62. Kabell, S.; Handberg, K.J.; Kusk, M.; Bisgaard, M. Detection of infectious bursal disease virus in various lymphoid tissues of experimentally infected specific pathogen free chickens by different reverse transcription polymerase chain reaction assays. Avian Dis. 2005, 49, 534-539. [CrossRef]

63. Kim, I.J.; You, S.K.; Kim, H.; Yeh, H.Y.; Sharma, J.M. Characteristics of bursal T lymphocytes induced by infectious bursal disease virus. J. Virol. 2000, 74, 8884-8892. [CrossRef] [PubMed]

64. Rautenschlein, S.; Yeh, H.Y.; Njenga, M.K.; Sharma, J.M. Role of intrabursal T cells in infectious bursal disease virus (IBDV) infection: T cells promote viral clearance but delay follicular recovery. Arch. Virol. 2002, 147, 285-304. [CrossRef]

65. Ruby, T.; Whittaker, C.; Withers, D.R.; Chelbi-Alix, M.K.; Morin, V.; Oudin, A.; Young, J.R.; Zoorob, R. Transcriptional profiling reveals a possible role for the timing of the inflammatory response in determining susceptibility to a viral infection. J. Virol. 2006, 80, 9207-9216. [CrossRef]

66. Eldaghayes, I.; Rothwell, L.; Williams, A.; Withers, D.; Balu, S.; Davison, F.; Kaiser, P. Infectious bursal disease virus: Strains that differ in virulence differentially modulate the innate immune response to infection in the chicken bursa. Viral Immunol. 2006, 19, 83-91. [CrossRef]

67. Liu, H.; Zhang, M.; Han, H.; Yuan, J.; Li, Z. Comparison of the expression of cytokine genes in the bursal tissues of the chickens following challenge with infectious bursal disease viruses of varying virulence. Virol. J. 2010, 7, 1-9. [CrossRef]

68. Heo, Y.T.; Lee, S.H.; Yang, J.H.; Kim, T.; Lee, H.T. Bone marrow cell-mediated production of transgenic chickens. Lab. Investig. 2011, 1229-1240. [CrossRef] [PubMed]

69. Rath, N.C.; Huff, G.R.; Huff, W.E.; Balog, J.M. Factors regulating bone maturity and strength in poultry. Poult. Sci. 2000, 79, 1024-1032. [CrossRef] [PubMed]

70. Yahyaei, B.; Gilanpour, H.; Veshkini, A. Study of the ossification centers and skeletal development of pelvic limb in quail after hatching. Adv. Environ. Biol. 2013, 2074-2081.

71. Iqbal, M.; Zhang, H.; Mehmood, K.; Li, A.; Jiang, X.; Wang, Y.; Zhang, J.; Iqbal, M.K.; Rehman, M.U.; Yao, W.; et al. Icariin: A potential compound for the recovery of Tibial Dyschondroplasia affected chicken via up-regulating BMP-2 expression. Biol. Proced. 2018, 20, 1-7. [CrossRef]

72. Fleming, R.H.; McCormack, H.A.; McTeir, L.; Whitehead, C.C. Incidence, pathology and prevention of keel bone deformities in the laying hen. Brit. Poult. Sci. 2004, 45, 320-330. [CrossRef]

73. Rodenburg, T.B.; Tuyttens, F.A.M.; De Reu, K.; Herman, L.; Zoons, J.; Sonck, B. Welfare assessment of laying hens in furnished cages and non-cage systems: An on-farm comparison. Anim. Welf. 2008, 17, 363-373.

74. Käppeli, S.; Gebhardt-Henrich, S.G.; Fröhlich, E.; Pfulg, A.; Stoffel, M.H. Prevalence of keel bone deformities in Swiss laying hens. Br. Poult. Sci. 2011, 52, 531-536. [CrossRef]

75. Wilkins, L.J.; McKinstry, J.L.; Avery, N.C.; Knowles, T.G.; Brown, S.N.; Tarlton, J.; Nicol, C.J. Influence of housing system and design on bone strength and keel bone fractures in laying hens. Vet. Rec. 2011, 169, 414. [CrossRef] [PubMed]

76. Petrik, M.T.; Guerin, M.T.; Widowski, T.M. On-farm comparison of keel fracture prevalence and other welfare indicators in conventional cage and floor-housed laying hens in Ontario, Canada. Poult. Sci. 2015, 94, 579-585. [CrossRef] [PubMed]

77. Toscano, M.J.; Dunn, I.C.; Christensen, J.P.; Petow, S.; Kittelsen, K.; Ulrich, R. Explanations for keel bone fractures in laying hens: Are there explanations in addition to elevated egg production? Poult. Sci. 2020, 99, 4183-4194. [CrossRef] [PubMed]

78. Chen, F.P.; Lee, N.; Wang, K.C.; Soong, Y.K.; Huang, K.E. Effect of estrogen and $1 \alpha, 25(\mathrm{OH}) 2$-vitamin D3 on the activity and growth of human primary osteoblast-like cells in vitro. Fertil. Steril. 2002, 77, 1038-1043. [CrossRef]

79. Jørgensen, N.R.; Henriksen, Z.; Sørensen, O.H.; Civitelli, R. Dexamethasone, BMP-2, and 1, 25-dihydroxyvitamin D enhance a more differentiated osteoblast phenotype: Validation of an in vitro model for human bone marrow-derived primary osteoblasts. Steroids 2004, 69, 219-226. [CrossRef] 
80. Li, X.; Liu, H.; Niu, X.; Yu, B.; Fan, Y.; Feng, Q.; Cui, F.; Watari, F. The use of carbon nanotubes to induce osteogenic differentiation of human adipose-derived MSCs in vitro and ectopic bone formation in vivo. Biomaterials 2012, 33, 4818-4827. [CrossRef]

81. Tourkova, I.L.; Liu, L.; Sutjarit, N.; Larrouture, Q.C.; Luo, J.; Robinson, L.J.; Blair, H.C. Adrenocorticotropic hormone and 1, 25-dihydroxyvitamin D 3 enhance human osteogenesis in vitro by synergistically accelerating the expression of bone-specific genes. Lab. Investig. 2017, 97, 1072-1083. [CrossRef]

82. Harrison, J.R.; Petersen, D.N.; Lichtler, A.C.; Mador, A.T.; Rowe, D.W.; Kream, B.E. 1, 25-Dihydroxyvitamin D3 inhibits transcription of type I collagen genes in the rat osteosarcoma cell line ROS 17/2.8. Endocrinology 1989, 125, 327-333. [CrossRef] [PubMed]

83. Kim, H.T.; Chen, T.L. 1, 25-Dihydroxyvitamin D3 interaction with dexamethasone and retinoic acid: Effects on procollagen messenger ribonucleic acid levels in rat osteoblast-like cells. Mol. Endocrinol. 1989, 3, 97-104. [CrossRef]

84. Van Driel, M.; Van Leeuwen, J.P. Vitamin D endocrine system and osteoblasts. Bonekey Rep. 2014, 3, 493. [CrossRef] [PubMed]

85. Chen, J.; Dosier, C.R.; Park, J.H.; De, S.; Guldberg, R.E.; Boyan, B.D.; Schwartz, Z. Mineralization of three-dimensional osteoblast cultures is enhanced by the interaction of 1 $\alpha, 25$-dihydroxyvitamin D3 and BMP2 via two specific vitamin D receptors. J. Tissue. Eng. Regen. Med. 2016, 10, 40-51. [CrossRef] [PubMed]

86. Kim, J.H.; Seong, S.; Kim, K.; Kim, I.; Jeong, B.C.; Kim, N. Downregulation of Runx2 by 1, 25-dihydroxyvitamin D3 induces the transdifferentiation of osteoblasts to adipocytes. Int. J. Mol. Sci. 2016, 17, 770. [CrossRef]

87. Xiong, Y.; Zhang, Y.; Xin, N.; Yuan, Y.; Zhang, Q.; Gong, P.; Wu, Y. 1 $\alpha$, 25-Dihydroxyvitamin D3 promotes osteogenesis by promoting Wnt signaling pathway. J. Steroid. Biochem. Mol. Biol. 2017, 174, 153-160. [CrossRef] [PubMed]

88. Broess, M.; Riva, A.; Gerstenfeld, L.C. Inhibitory effects of 1, $25(\mathrm{OH}) 2$ vitamin D3 on collagen type I, osteopontin, and osteocalcin gene expression in chicken osteoblasts. J. Cell. Bibiochem. 1995, 57, 440-451. [CrossRef]

89. Pande, V.V.; Chousalkar, K.C.; Bhanugopan, M.S.; Quinn, J.C. Super pharmacological levels of calcitriol (1, 25-(OH) 2 D3) inhibits mineral deposition and decreases cell proliferation in a strain dependent manner in chicken mesenchymal stem cells undergoing osteogenic differentiation in vitro. Poult. Sci. 2015, 94, 2784-2796. [CrossRef]

90. Gil, A.; Plaza-Diaz, J.; Mesa, M.D. Vitamin D: Classic and novel actions. Ann. Nutr. Metab. 2018, 72, 87-95. [CrossRef]

91. Milford, A.B.; Le Mouël, C.; Bodirsky, B.L.; Rolinski, S. Drivers of meat consumption. Appetite 2019, 141, 104313. [CrossRef] [PubMed]

92. Basu, S. The transitional dynamics of caloric ecosystems: Changes in the food supply around the world. Crit. Public Health. 2015, 25, 248-264. [CrossRef]

93. Al-Khalaifa, H.; Al-Nasser, A.; Al-Surayee, T.; Al-Kandari, S.; Al-Enzi, N.; Al-Sharrah, T.; Ragheb, G.; Al-Qalaf, S.; Mohammed, A. Effect of dietary probiotics and prebiotics on the performance of broiler chickens. Poult. Sci. 2019, 98, 4465-4479. [CrossRef] [PubMed]

94. Sohail, M.U.; Hume, M.E.; Byrd, J.A.; Nisbet, D.J.; Ijaz, A.; Sohail, A.; Shabbir, M.Z.; Rehman, H. Effect of supplementation of prebiotic mannan-oligosaccharides and probiotic mixture on growth performance of broilers subjected to chronic heat stress Poult. Sci. 2012, 91, 2235-2240. [CrossRef] [PubMed]

95. Alavi, S.A.N.; Zakeri, A.; Kamrani, B.; Pourakbari, Y. Effect of prebiotics, probiotics, acidfire, growth promoter antibiotics and synbiotic on humural immunity of broiler chickens. Global Vet. 2012, 8, 612-617.

96. Maiorano, G.; Stadnicka, K.; Tavaniello, S.; Abiuso, C.; Bogucka, J.; Bednarczyk, M. In ovo validation model to assess the efficacy of commercial prebiotics on broiler performance and oxidative stability of meat. Poult. Sci. 2017, 96, 511-518. [CrossRef]

97. Carrade, D.D.; Borjesson, D.L. Immunomodulation by mesenchymal stem cells in veterinary species. Com. Med. 2013, 63, 207-217.

98. Lotfinegad, P. Immunomodulatory nature and site specific affinity of mesenchymal stem cells: A hope in cell therapy. Adv. Pharm. Bull. 2014, 4, 5. [CrossRef]

99. Zimmermann, K.; Haas, A.; Oxenius, A. Systemic antibody responses to gut microbes in health and disease. Gut Microbes 2012, 3, 42-47. [CrossRef]

100. Li, G.; Lillehoj, H.S.; Lee, K.W.; Jang, S.I.; Marc, P.; Gay, C.G.; Ritter, G.D.; Bautista, D.A.; Phillips, K.; Neumann, A.P.; et al. An outbreak of gangrenous dermatitis in commercial broiler chickens. Avian Path. 2010, 39, 247-253. [CrossRef]

101. McDevitt, R.M.; Brooker, J.D.; Acamovic, T.; Sparks, N.H.C. Necrotic enteritis; a continuing challenge for the poultry industry. World's Poul. Sci. J. 2006, 62, 221-247. [CrossRef]

102. Mataragas, M.; Skandamis, P.N.; Drosinos, E.H. Risk profiles of pork and poultry meat and risk ratings of various pathogen/product combinations. Int. J. Food Microbiol. 2008, 126, 1-12. [CrossRef] [PubMed]

103. Cooper, K.K.; Songer, J.G. Necrotic enteritis in chickens: A paradigm of enteric infection by Clostridium perfringens type A. Anaerobe 2009, 15, 55-60. [CrossRef] [PubMed]

104. Van Immerseel, F.; Rood, J.I.; Moore, R.J.; Titball, R.W. Rethinking our understanding of the pathogenesis of necrotic enteritis in chickens. Trends Microbiol. 2009, 17, 32-36. [CrossRef]

105. Gornatti-Churria, C.D.; Crispo, M.; Shivaprasad, H.L.; Uzal, F.A. Gangrenous dermatitis in chickens and turkeys. J. Vet. Diag. Investig. 2018, 30, 188-196. [CrossRef]

106. Shivaprasad, H.L. Gangrenous dermatitis in poultry. In Clostridial Diseases of Animals; Wiley-Blackwell: Ames, IA, USA, 2016; pp. 255-264.

107. Dinev, I.; Denev, S.; Vashin, I.; Kanakov, D.; Rusenova, N. Pathomorphological investigations on the prevalence of contact dermatitis lesions in broiler chickens. J. Appl. Anim. Res. 2019, 47, 129-134. [CrossRef] 
108. Li, G.; Lillehoj, H.S.; Lee, K.W.; Lee, S.H.; Park, M.S.; Jang, S.I.; Bauchan, G.R.; Gay, C.G.; Ritter, G.D.; Bautista, D.A.; et al. Immunopathology and cytokine responses in commercial broiler chickens with gangrenous dermatitis. Avian Pathol. 2010, 39, 255-264. [CrossRef]

109. Golchin, A.; Farahany, T.Z.; Khojasteh, A.; Soleimanifar, F.; Ardeshirylajimi, A. The clinical trials of mesenchymal stem cell therapy in skin diseases: An update and concise review. Curr. Stem Cell Res. Ther. 2019, 14, 22-33. [CrossRef]

110. Steinfeld, H.; Gerber, P.; Wassenaar, T.D.; Castel, V.; Rosales, M.; Rosales, M.; de Haan, C. Livestock's Long Shadow: Environmental Issues and Options; Food Agriculture Organization: Rome, Italy, 2006.

111. Hoekstra, A.Y.; Chapagain, A.K. Water footprints of nations: Water use by people as a function of their consumption pattern. In Integrated Assessment of Water Resources and Global Change; Springer: Dordrecht, The Netherlands, 2006; pp. $35-48$.

112. Fiala, N. Meeting the demand: An estimation of potential future greenhouse gas emissions from meat production. Ecol. Econom. 2008, 67, 412-419. [CrossRef]

113. Sutton, T.C. The pandemic threat of emerging H5 and H7 avian influenza viruses. Viruses 2018, 10, 461. [CrossRef]

114. Park, S.E. Epidemiology, virology, and clinical features of severe acute respiratory syndrome-coronavirus-2 (SARS-CoV-2 Coronavirus Disease-19). Clin. Exp. Pediatr. 2020, 63, 119. [CrossRef] [PubMed]

115. Stanton, M.M.; Tzatzalos, E.; Donne, M.; Kolundzic, N.; Helgason, I.; Ilic, D. Prospects for the use of induced pluripotent stem cells in animal conservation and environmental protection. Stem Cells Transl. Med. 2019, 8, 7-13. [CrossRef]

116. Datar, I.; Betti, M. Possibilities for an in vitro meat production system. Innov. Food. Sci. Emerg. Technol. 2010, 11, 13-22. [CrossRef]

117. Arshad, M.S.; Javed, M.; Sohaib, M.; Saeed, F.; Imran, A.; Amjad, Z. Tissue engineering approaches to develop cultured meat from cells: A mini review. Cogent Food Agric 2017, 3, 1320814. [CrossRef]

118. Bhat, Z.F.; Kumar, S.; Fayaz, H. In Vitro meat production: Challenges and benefits over conventional meat production. J. Integr. Agric. 2015, 14, 241-248. [CrossRef]

119. Will, K.; Schering, L.; Albrecht, E.; Kalbe, C.; Maak, S. Differentiation of bovine satellite cell-derived myoblasts under different culture conditions. In Vitro. Cell. Dev. Biol. Animal 2015, 51, 885-889. [CrossRef] [PubMed]

120. Ostrovidov, S.; Ahadian, S.; Ramon-Azcon, J.; Hosseini, V.; Fujie, T.; Parthiban, S.P.; Khademhosseini, A. Three-dimensional co-culture of $\mathrm{C} 2 \mathrm{C} 12 / \mathrm{PC} 12$ cells improves skeletal muscle tissue formation and function. J. Tissue Eng. Regen. Med. 2017, 11, 582-595. [CrossRef] [PubMed]

121. Mehta, F.; Theunissen, R.; Post, M.J. Adipogenesis from bovine precursors. In Myogenesis; Humana Press: New York, NY, USA, 2019; pp. 111-125. [CrossRef]

122. Cremonesi, F.; Corradetti, B.; Consiglio, A.L. Fetal adnexa derived stem cells from domestic animal: Progress and perspectives. Theriogenology 2001, 75, 1400-1415. [CrossRef]

123. Wang, Y.; Han, Z.B.; Song, Y.P.; Han, Z.C. Safety of mesenchymal stem cells for clinical application. Stem Cells Int. 2012, 652034. [CrossRef] [PubMed]

124. Bai, C.; Li, C.; Jin, D.; Guo, Y.; Guan, W.; Ma, Y.; Zhao, Q. Establishment and characterization of a fibroblast line from landrace. Artif. Cell Blood Sub. 2010, 38, 129-135. [CrossRef]

125. Na, R.S.; Zhao, Q.J.; Su, X.H.; Chen, X.W.; Guan, W.J.; Ma, Y.H. Establishment and biological characteristics of Ujumqin sheep fibroblast line. Cytotechnology 2010, 62, 43-52. [CrossRef] [PubMed] 